\title{
Benthic macrofauna communities of the submersed Pleistocene Elbe valley in the southern North Sea
}

\author{
Peter Rehm • Eike Rachor
}

Received: 1 January 2006 / Revised: 8 January 2007 / Accepted: 15 January 2007 / Published online: 15 February 2007

(C) Springer-Verlag and AWI 2007

\begin{abstract}
Macrozoobenthic community structure was studied in two surveys along a transect of 13 stations following the submersed Pleistocene Elbe valley in the south-eastern North Sea during May to June 2000 and March 2001. Two replicates of bottom samples were taken with a van Veen grab of $0.1 \mathrm{~m}^{2}$ sampling size. In order to analyse the benthic macrofauna communities, the animals obtained were identified and counted, and MDS and cluster analysis were performed. Out of 200 taxa identified, 84 were polychaetes, 46 molluscs, 40 crustaceans, 15 echinoderms, and 15 belonged to other groups. Mean abundance was 4,860 individuals per $\mathrm{m}^{2}$, mean biomass $32.9 \mathrm{~g}$ ash free dry mass per $\mathrm{m}^{2}$. Mean diversity was 1.76 and mean evenness 0.54 . The macrofauna of the Pleistocene Elbe valley is composed of three associations according to the cluster analysis. Each association is described by a combination of characterizing and discriminating species. An Amphiura-brachiata-Tellimya-ferruginosa-association was found in the south-eastern part of the depression, whereas a transitional association with elements of both assemblages lead to an Amphiura-filiformis - Galathowenia-oculata - Nuculoma-tenuis-association in the north-western part of the valley. In the context of the entire southern North Sea, both associations are small-scale substructures, and as such are
\end{abstract}

Communicated by H.-D. Franke.

P. Rehm $(\varangle) \cdot$ E. Rachor

Alfred Wegener Institute for Polar and Marine Research

(AWI), Marine Animal Ecology, Am Alten Hafen 26,

27568 Bremerhaven, Germany

e-mail: peter.rehm@awi.de contained in the Nucula-nitidosa-community and the Amphiura-filiformis-community, respectively. A northwestward shift of the community of the southern Elbe valley was found and discussed as a possible consequence of warm winters of the last decades.

Keywords Benthic communities - Macrozoobenthos · North Sea $\cdot$ Pleistocene Elbe valley

\section{Introduction}

The macrozoobenthos of the offshore North Sea has been the subject of scientific studies since the end of the 19th century. The first quantitative work was conducted by Petersen (1914) and Hagmeier (1925). The main objects of these early studies were related to fish biology. Later studies aimed at creating detailed pictures of the biotic community structure of the seafloor and its connections to biotopes, pollutions, and nature conservation (e.g. Caspers 1939; Stripp 1969; Salzwedel et al. 1985; Duineveld et al. 1991; Heip et al. 1992; Künitzer et al. 1992; Rachor and Nehmer 2003). Gear and methods employed have constantly been improved, and with the introduction of computers the possibility arose to analyse vast amounts of data from exhaustive surveys with statistical methods (Salzwedel et al. 1985).

Unusual, geographically limited structures such as the Pleistocene Elbe Valley and the Helgoland Deep Trench with their special hydrographical characteristics were of particular interest for scientific studies (Caspers 1939; Figge 1980; Rachor and Albrecht 1983; Büsselberg 1985; Berberich 1989; Künitzer 1990). The valley is a depression in the seafloor, 
Fig. 1 Macrozoobenthos study sites in the Pleistocene Elbe valley (southern North Sea); positions of stations 471 and $\mathrm{U} 13$ are identical

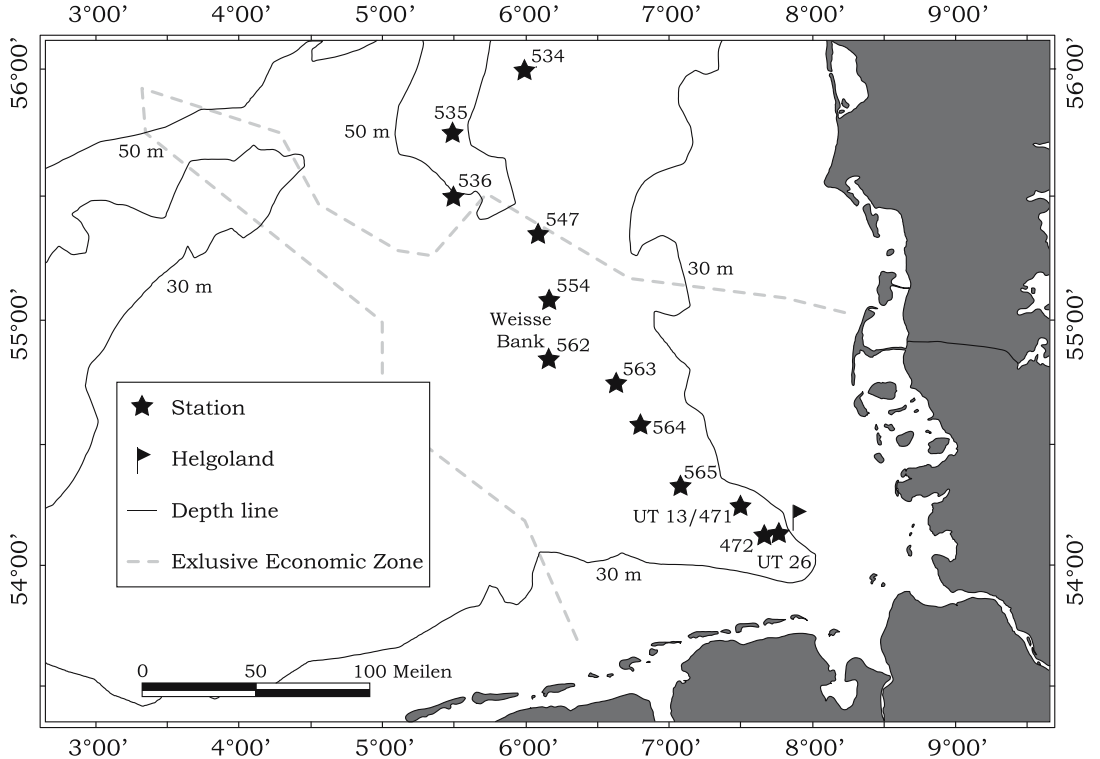

where cold bottom water can be advected along the valley into the German Bight. Furthermore, during the years from 1981 to 1983, low oxygen was recorded in bottom waters of the valley, which led to damaged fauna of the neighbouring seafloor (Rachor and Albrecht 1983).

The analysis of the macrozoobenthos of the Pleistocene Elbe valley carried out in 1984 was limited to the south-eastern and central parts of the valley from west of the island of Helgoland to east of the Weisse Bank (Büsselberg 1985). In 1990, the valley was investigated along its whole length, but the emphasis of that study was on seasonal variability of environmental parameters in the central North Sea (Künitzer 1990).

The aim of the present study is to describe the macrozoobenthic community structure of the whole Pleistocene Elbe valley in order to evaluate possible changes in the communities of the area by a comparison with the above previous studies. Another aim is the evaluation of the valley, its habitats, and communities with respect to their role in nature protection concepts. The valley is important in netting soft bottom habitats with the rocky habitats off Helgoland, as the eastern slope includes pebbles, stone fields, and erratic blocks. In this area, communities are tightly interlocked and display high-species diversity. Furthermore, in deeper habitats of the valley, salinity is relatively stable and the fluctuation of temperature is less intensive than in shallow waters near the cost. Thus, the valley serves as a retreat and an area of regeneration for some species (Rachor and Nehmer 2003).

\section{Methods}

Study area

During the last European glaciation until about 15,000 years ago, most of the present seafloor of the North Sea was above the waterline. Many structures in seabed morphology can be tracked back to that time (Becker 1990). The Pleistocene Elbe valley, situated in the south-eastern North Sea (Fig. 1), is the most conspicuous relict from that period. The former riverbed of the Elbe can still be distinguished from the surrounding seafloor as a channel $\sim 25-40 \mathrm{~km}$ wide extending from the Southeast (including the Helgoland Deep Trench, which is also influenced by tectonic processes) to the Northwest of the German Bight up to the Dogger Bank. As such, it has peculiar hydrographical features, which have attracted much attention of various investigations in the past (Caspers 1939; Figge 1980; Rachor and Albrecht 1983; Büsselberg 1985; Berberich 1989; Künitzer 1990).

\section{Sampling of macrozoobenthos}

Macrozoobenthos was sampled at 13 stations in the Pleistocene Elbe valley using a van Veen grab of $0.1 \mathrm{~m}^{2}$ sampling size during cruisees onboard RV "Heincke" in May and June 2000 and onboard RV "Uthörn" in March 2002, respectively (Fig. 1, Table 1). Sampling during summer 2000 took place in the setting of the project "Erfassung und Bewertung ökologisch wertvoller Lebensräume in der Nordsee" of the German Federal Agency for Nature Conservation (BfN) (Rachor 
Table 1 Sampling and boitic data of the macrozoobenthic comunities of the Pleistocene Elbe valley (southern North Sea)

\begin{tabular}{|c|c|c|c|c|c|c|c|c|c|c|}
\hline \multirow[t]{2}{*}{ Cluster/station } & \multicolumn{2}{|l|}{ Position } & \multirow{2}{*}{$\begin{array}{l}\text { Depth } \\
\text { (m) }\end{array}$} & \multirow{2}{*}{ Sediment } & \multirow{2}{*}{$\begin{array}{l}\text { Species } \\
\text { number }\end{array}$} & \multirow{2}{*}{$H^{\prime}$} & \multirow[t]{2}{*}{$J^{\prime}$} & \multirow[t]{2}{*}{$S(90 \%)$} & \multirow{2}{*}{$\begin{array}{l}\text { Abundance } \\
\text { (ind } \mathrm{m}^{-2} \text { ) }\end{array}$} & \multirow[t]{2}{*}{ Biomass $\left(\mathrm{g}^{-2}\right)$} \\
\hline & $\begin{array}{l}\text { Latitude } \\
(\mathrm{N})\end{array}$ & $\begin{array}{l}\text { Longitude } \\
\text { (E) }\end{array}$ & & & & & & & & \\
\hline Southeast & & & & & 76 & $2.26(2.45) \mathrm{m}$ & $0.67(0.69) \mathrm{m}$ & $15(22)$ & $4575(2705) \mathrm{m}$ & $42.47(24.12) \mathrm{m}$ \\
\hline UT26 & $54^{\circ} 08.04^{\prime}$ & $07^{\circ} 45.92^{\prime}$ & 38 & s FS & 43 & $0.9(2.74)$ & $0.24(0.73)$ & $3(19)$ & $9920(1940)$ & $99.71(15.17)$ \\
\hline UT13 & $54^{\circ} 14.87^{\prime}$ & $07^{\circ} 30.56^{\prime}$ & 40 & $\mathrm{~m} \mathrm{FS}$ & 40 & $1.41(2.14)$ & $0.38(0.58)$ & $6(16)$ & $7110(2700)$ & $66.65(43.15)$ \\
\hline 472 & $54^{\circ} 08.10^{\prime}$ & $07^{\circ} 40.07^{\prime}$ & 40 & $\mathrm{~m} \mathrm{FS}$ & 39 & 2.58 & 0.71 & 16 & 5700 & 57.85 \\
\hline 471 & $54^{\circ} 15.09^{\prime}$ & $07^{\circ} 30.00^{\prime}$ & 41 & FS & 34 & 2.67 & 0.76 & 18 & 1945 & 27.09 \\
\hline 565 & $54^{\circ} 34.90^{\prime}$ & $06^{\circ} 47.97^{\prime}$ & 41 & $\mathrm{mFS}$ & 27 & 2.2 & 0.67 & 10 & 3450 & 18.97 \\
\hline 564 & $54^{\circ} 19.96^{\prime}$ & $07^{\circ} 05.19^{\prime}$ & 39 & $\mathrm{~m} \mathrm{FS}$ & 34 & 2.32 & 0.66 & 15 & 2710 & 21.14 \\
\hline Central & & & & & 49 & $2.17 \mathrm{~m}$ & $0.62 \mathrm{~m}$ & 14 & $3528 \mathrm{~m}$ & $21.51 \mathrm{~m}$ \\
\hline 563 & $54^{\circ} 45.09^{\prime}$ & $06^{\circ} 38.00^{\prime}$ & 41 & $\mathrm{~m} \mathrm{FS}$ & 40 & 2.17 & 0.59 & 11 & 5200 & 28.28 \\
\hline 562 & $54^{\circ} 51.94^{\prime}$ & $06^{\circ} 09.91^{\prime}$ & 40 & $\mathrm{~m} \mathrm{FS}$ & 29 & 2.17 & 0.64 & 12 & 1855 & 14.74 \\
\hline Northwest & & & & & 82 & $1.62 \mathrm{~m}$ & $0.44 \mathrm{~m}$ & 11 & $6528 \mathrm{~m}$ & $22.7 \mathrm{~m}$ \\
\hline 554 & $55^{\circ} 04.92^{\prime}$ & $06^{\circ} 09.76$ & 47 & $\mathrm{~m} \mathrm{FS}$ & 40 & 1.44 & 0.39 & 4 & 6945 & 26.80 \\
\hline 536 & $55^{\circ} 29.98^{\prime}$ & $05^{\circ} 29.94^{\prime \prime}$ & 53 & fs $M$ & 42 & 1.79 & 0.48 & 11 & 6110 & 28.59 \\
\hline 535 & $55^{\circ} 45.11^{\prime}$ & $05^{\circ} 30.21^{\prime}$ & 54 & fs M & 46 & 1.66 & 0.43 & 7 & 7090 & 18.59 \\
\hline 534 & $56^{\circ} 00.00^{\prime}$ & $05^{\circ} 59.07^{\prime}$ & 48 & fs SI & 34 & 1.57 & 0.45 & 12 & 3440 & 12.46 \\
\hline Single station & & & & & & & & & & \\
\hline $547^{\circ}$ & $50^{\circ} 20.98^{\prime}$ & $06^{\circ} 04.96^{\prime}$ & 49 & s M & 21 & 1.33 & 0.44 & 5 & 1700 & 7.37 \\
\hline
\end{tabular}

Values in brackets were calculated with Phoronis spp. excluded, $H^{\prime}$ diversity (Shannon and Weaver 1949), $J^{\prime}$ evenness (Pielou 1966), $m$ median, ind individuals, sediment types: $F S$ fine sand, $M$ mud, $S I$ silt, $f s$ fine sandy, $m$ muddy, $s$ sandy

2006). Two replicates were taken at each station. Samples were sieved over $1 \mathrm{~mm}$ meshes and preserved in $5 \%$ buffered formalin. Biomass is given in ash free dry mass and calculated from wet mass using conversion factors provided by Brey (2001).

\section{Community analysis}

Differences in the structure of the benthic fauna of the valley were elaborated by running cluster analysis as well as MDS. Juvenile animals were removed from the species list before running the community analysis to exclude seasonal effects caused by different times of sampling during the years 2000 and 2001. Stations were grouped according to the results of the cluster analysis as well as MDS. The similarity matrix of both methods was calculated with Bray-Curtis-Index (Bray and Curtis 1957); after a fourth root transformation, the group average method was applied. Analyses were carried out with the programme Primer (Version 5.1.2).

\section{Characterization of station groups}

Diversity $H^{\prime}$ (Shannon and Weaver 1949), evenness $J^{\prime}$ (Pielou 1966), and $S(90 \%)$ that gives the number of species, which represent $90 \%$ of the individuals, were calculated to characterize station groups obtained from cluster analysis and MDS. For further description of the communities, characterizing species (Salzwedel et al. 1985) as well as discriminating species (Clarke and Warwick 1994) were identified.
After Salzwedel et al. (1985) characterizing species are determined out of those with a numerical dominance greater than $1 \%$ within a certain station group, if they satisfy at least three of the following conditions:

- numerical dominance within the station group higher than $5 \%$,

- presence within the station group higher than $80 \%$,

- fidelity of abundance (FA) (degree of association regarding individuals DAI) higher than $66 \%$, or

- fidelity of presence (FP) (degree of associations regarding stations DAS) higher than $66 \%$.

The expressions of DAI and DAS introduced by Salzwedel et al. (1985) were renamed by FA and FP (Rehm 2002).

Discriminators were calculated as shown by Clarke and Warwick (1994). A suitable discriminator is a species $k$, which shares as much dissimilarity $\delta_{k}$ as possible of the dissimilarity $\delta$ of two station groups. In addition, the species should be distributed evenly over the station group, which means the standard deviation $\operatorname{SD}\left(\delta_{k}\right)$ should be low. Therefore, suitable discriminators are characterized by high values of $\delta_{k} / \mathrm{SD}\left(\delta_{k}\right)$.

\section{Results}

Macrobenthic community structure

As shown in Fig. 2, there are three clusters at a similarity level of $45 \%$ and a single outgrouping station (547). 


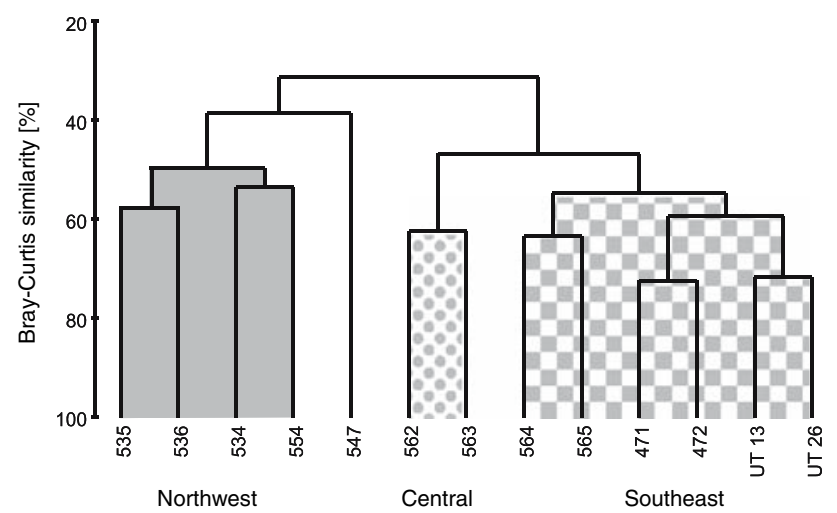

Fig. 2 Cluster analysis of macrozoobenthic abundance calculated with Bray-Curtis similarity; forth root transformation and group average method were applied

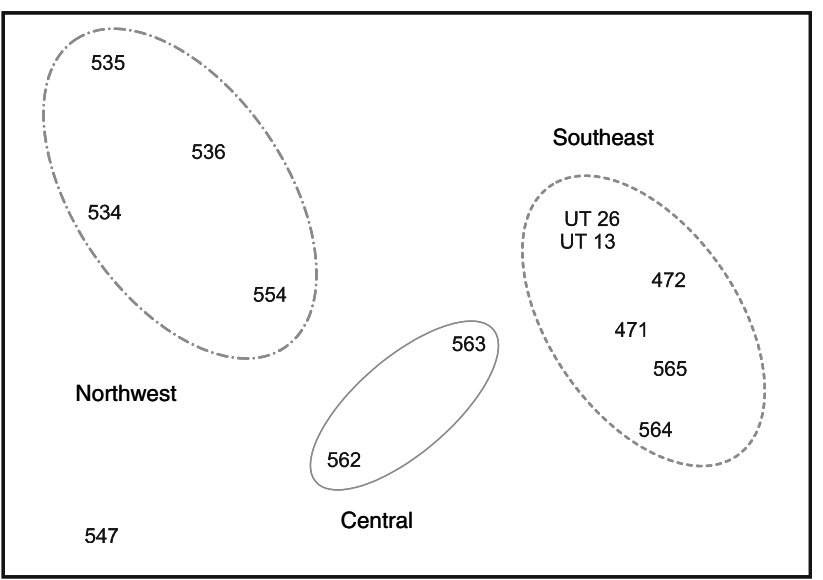

Fig. 3 MDS plot on macrozoobenthic abundance calculated with Bray-Curtis similarity and fourth root transformation; stress $=0.07$

According to the geographic arrangement along the Elbe valley, the clusters were named Northwest, Central, and Southeast. At a similarity level of $30 \%$, the Pleistocene Elbe valley is divided into two clusters only, the first containing the station groups Central and Southeast, the second Northwest, now joined with the single station 547.

No distinct station groups are visible from the MDS (Fig. 3). Only stations of cluster Southeast are closer to each other than most of the other stations and confirmed by the MDS, while station 547 is again separated from all other stations. The distance between the stations of groups Northwest and Central is similar; however, the arrangement of the stations again roughly resembles the geographical arrangement along the Pleistocene Elbe valley. Evenly distributed stations along the valley display a gradual change of macrobenthic communities.
Characterization of the communities

Differences in biotic features between the station groups for species number, diversity, evenness, and $S$ $(90 \%)$ are shown in Table 1 . Species number is lowest in the central group, where only four grabs were taken. Diversity, evenness, and $S(90 \%)$ decrease from coastal stations towards the open sea. Exceptions of this trend are stations UT13 and UT26, due to mass occurrences of Phoronis spp. in 2001. After the exclusion of Phoronis spp., the values of diversity, evenness, and $S$ (90\%) correspond with those of the remaining stations of station group Southeast.

The variation in biomass is very high. However, biomass at stations UT13, UT26, and 472 is noteworthy, as the values are exceptionally high. Again, for UT26, this is due to the mass occurrence of Phoronis spp, which does not, however, apply for stations UT13 and 472 (Table 1).

Salzwedel et al. (1985) picked characterizing species out of those which had dominances within an association of at least $1 \%$. In station group Northwest, three characterizing species were identified, and seven in station group Southeast (Table 2). In contrast to the high number of characterizing species in the latter group, in station group Central no species fulfilled the criteria.

Unlike characterizing species, discriminators are important for separation of two station groups. Dominance is less important than the contribution of species to the average dissimilarity $\delta$. Generally, discriminators and characterizing species do not have to be identical. Most important discriminators for the station group Southeast are the ophiurid Amphiura brachiata and the bivalve Tellimya ferruginosa (Table 3). Station group Central is mainly characterized by two discriminators, the amphipod Harpinia antennaria and the bivalve Abra nitida. Important discriminators of station group Northwest are Amphiura filiformis, H. antennaria, and the cnidarian Cerianthus lloydii. All these discriminators are characterized by their contribution to dissimilarity against both the other station groups or by complete absence in at least one station group.

Based on the analysis of community characterizing species, a north-western Amphiura-filiformis - Galathowenia-oculata -Nuculoma-tenuis-association was identified. The central association is a transitional one with elements of both the other associations and without characterizing species. Considering the high number of characterizing species in station group Southeast, the association in the southern part of the Pleistocene Elbe valley was named by species which were 
Table 2 Characterization of species, which occurred with dominance $\geq 1 \%$ in the associations of the Pleistocene Elbe valley (southern North Sea)

Ind individuals $\mathrm{m}^{-2}$, med median, min minimum numbers of species, max maximum numbers of species, dom numerical dominance (\%), pre presence (\%), Biv bivalvia, Cru crustacea, Ech echinodermata Gas gastropoda, Pol polychaeta, Ten tentaculata, $F A$ fidelity of abundance, $F P$ fidelity of presence, characterizing species after Salzwedel et al. (1985) are printed in bold letters

\begin{tabular}{|c|c|c|c|c|c|c|c|c|c|c|}
\hline Cluster/species & Taxon & ind & med & mean & $\min$ & $\max$ & dom & pre & FA & FP \\
\hline \multicolumn{11}{|l|}{ Southeast } \\
\hline Phoronis spp. & Ten & 13870 & 688 & 2312 & 30 & 7980 & 50.4 & 100.0 & 98.1 & 54.5 \\
\hline Nucula nitidosa & Biv & 3185 & 550 & 531 & 55 & 1075 & 11.6 & 100.0 & 75.5 & 60.0 \\
\hline Owenia fusiformis & Pol & 1980 & 75 & 330 & 10 & 1275 & 7.2 & 100.0 & 88.9 & 60.0 \\
\hline Abra alba & Biv & 1406 & 23 & 234 & 0 & 1240 & 5.1 & 83.3 & 100.0 & 100.0 \\
\hline Scalibregma inflatum & Pol & 1090 & 80 & 182 & 0 & 760 & 4.0 & 83.3 & 99.9 & 83.3 \\
\hline Amphiura brachiata & Ech & 630 & 105 & 105 & 70 & 155 & 2.3 & 100.0 & 100.0 & 100.0 \\
\hline Phaxas pellucidus & Biv & 460 & 40 & 77 & 25 & 205 & 1.7 & 100.0 & 87.3 & 60.0 \\
\hline Tellimya ferruginosa & Biv & 435 & 70 & 73 & 35 & 125 & 1.6 & 100.0 & 95.6 & 85.7 \\
\hline Nephtys hombergii & Pol & 370 & 58 & 62 & 25 & 105 & 1.3 & 100.0 & 64.9 & 50.0 \\
\hline Corbula gibba & Biv & 326 & 33 & 54 & 0 & 140 & 1.2 & 83.3 & 10.0 & 50.0 \\
\hline $\begin{array}{l}\text { Mysella bidentata } \\
\text { Central }\end{array}$ & Biv & 335 & 60 & 56 & 0 & 115 & 1.2 & 66.7 & 33.0 & 40.0 \\
\hline Amphiura filiformis & Ech & 1780 & 890 & 890 & 625 & 1155 & 36.6 & 100.0 & 15.9 & 22.2 \\
\hline Nucula nitidosa & Biv & 1000 & 500 & 500 & 45 & 955 & 20.5 & 100.0 & 23.7 & 20.0 \\
\hline Corbula gibba & Biv & 540 & 270 & 270 & 125 & 415 & 11.1 & 100.0 & 16.6 & 20.0 \\
\hline Phoronis spp. & Ten & 220 & 110 & 110 & 60 & 160 & 4.5 & 100.0 & 1.6 & 18.2 \\
\hline Owenia fusiformis & Pol & 220 & 110 & 110 & 0 & 220 & 4.5 & 50.0 & 9.9 & 10.0 \\
\hline Nephtys hombergii & Pol & 105 & 53 & 53 & 35 & 70 & 2.2 & 100.0 & 18.4 & 16.7 \\
\hline Polinices pulchellus & Gas & 100 & 50 & 50 & 40 & 60 & 2.1 & 100.0 & 27.0 & 20.0 \\
\hline Spiophanes bombyx & Pol & 85 & 43 & 43 & 30 & 55 & 1.7 & 100.0 & 20.0 & 18.2 \\
\hline Pholoe baltica & Pol & 85 & 43 & 43 & 40 & 45 & 1.7 & 100.0 & 14.4 & 18.2 \\
\hline Magelona filiformis & Pol & 80 & 40 & 40 & 30 & 50 & 1.6 & 100.0 & 52.6 & 33.3 \\
\hline Phaxas pellucidus & Biv & 65 & 33 & 33 & 15 & 50 & 1.3 & 100.0 & 12.3 & 20.0 \\
\hline Corystes cassivelaunus & Cru & 55 & 28 & 28 & 25 & 30 & 1.1 & 100.0 & 40.1 & 25.0 \\
\hline Thyasira flexuosa & Biv & 55 & 28 & 28 & 0 & 55 & 1.1 & 50.0 & 20.7 & 12.5 \\
\hline Northwest & & & & & & & & & & \\
\hline Amphiura filiformis & Ech & 8345 & 2053 & 2086 & 1270 & 2970 & 48.0 & 100.0 & 74.6 & 44.4 \\
\hline Galathowenia oculata & Pol & 3211 & 105 & 803 & 1 & 3000 & 18.5 & 100.0 & 100.0 & 100.0 \\
\hline Corbula gibba & Biv & 2085 & 10 & 521 & 0 & 2065 & 12.0 & 50.0 & 63.9 & 20.0 \\
\hline Mysella bidentata & Biv & 635 & 158 & 159 & 25 & 295 & 3.7 & 100.0 & 62.5 & 40.0 \\
\hline Pholoe baltica & Pol & 390 & 73 & 98 & 35 & 210 & 2.2 & 100.0 & 66.0 & 36.4 \\
\hline Lanice conchilega & Pol & 305 & 68 & 76 & 0 & 170 & 1.8 & 50.0 & 68.8 & 25.0 \\
\hline Lagis koreni & Pol & 222 & 11 & 56 & 1 & 200 & 1.3 & 100.0 & 75.0 & 33.3 \\
\hline Nuculoma tenuis & Biv & 186 & 30 & 47 & 1 & 125 & 1.1 & 100.0 & 100.0 & 100.0 \\
\hline Diplocirrus glaucus & Pol & 186 & 20 & 46.5 & 1 & 145 & 1.1 & 100.0 & 91.6 & 57.1 \\
\hline
\end{tabular}

Pleistocene Elbe valley, however, biomass values were comparable to those formerly measured. In 1995, correspondingly high biomasses were found to the East off Helgoland (Thatje and Gerdes 1997). At the border of the muddy-sandy area south of Helgoland, biomass reached a maximum of $2,470 \mathrm{gm}^{-2}$ wet mass, which was ascribed to a mass occurrence of the polychaete Lanice conchilega. As the high biomasses of this study are ascribed to mass occurrences of Phoronis spp., differences with other studies should not be overestimated. Rachor (1990) stated an increased biomass in 1975 due to eutrophication in comparison to the survey carried out by Hagmeier (1925) in 1923. It is supposed that the trend of increased eutrophication has continued until nowadays (Kröncke and Rachor 1992; Rachor and Nehmer 2003). Recent observations from long term community data off Helgoland (Schröder 2003) support the suggestion that the ecosystem of the inner German bight showed a trend back towards the state of the 1970s (Radach 1998). 
Table 3 Discriminating species of the clusters of the Pleistocene Elbe valley (southern North Sea)

\begin{tabular}{llllll}
\hline Compared clusters/species & Taxon & Average abundance $\left(\mathrm{m}^{-2}\right)$ & Ind dom & $\delta_{k}$ & $\delta_{k} / \mathrm{SD}\left(\delta_{k}\right)$
\end{tabular}

(a)

(b)

Southeast (a) and Northwest (b), $\delta=70.71$

Amphiura filiformis Ech $\quad 3.5$

$\begin{array}{llr}\text { Amphiura brachiata } & \text { Ech } & 105.0\end{array}$

$\begin{array}{lll}\text { Tellimya ferruginosa } & \text { Biv } & 72.5\end{array}$

Harpinia antennaria $\quad$ Cru $\quad 0.0$

Southeast (a) and Central (b), $\delta=53.36$

Amphiura filiformis $\quad$ Ech $\quad 3.5$

$\begin{array}{llr}\text { Amphiura brachiata } & \text { Ech } & 105.0\end{array}$

$\begin{array}{llr}\text { Abra nitida } & \text { Biv } & 46.7\end{array}$

Harpinia antennaria $\quad$ Cru $\quad 0.0$

Ophiodromus flexuosus $\quad$ Pol $\quad 1.7$

$\begin{array}{lll}\text { Cylichna cylindracea } \quad \text { Gas } & 7.5\end{array}$

Northwest (a) and Central (b), $\delta=58.04$

Mysella bidentata

Phoronis spp.

Biv $\quad 158.8$

Magelona filiformis

Ten $\quad 0.5$

Abra nitida

Cerianthus lloydii

Pol $\quad 0.3$

Biv $\quad 0.0$

Ind dom dominance of individuals in compared clusters $(\%), \delta$ share of dissimilarity of species $k, \delta$ average dissimilarity, $S D$ standard deviation, Biv Bivalvia, Cni Cnidaria, Cru Crustacea, Ech Echinodermata, Gas Gastropoda, Pol Polychaeta, Ten Tentaculata

Within the valley, diversity and evenness decreased with increasing distance to the coast (towards the northern end of the valley). This is in contradiction to other investigations (Heip et al. 1992; Kröncke and Rachor 1992), but shows a good correlation to the data from the intermediate part of the Pleistocene Elbe valley presented by Salzwedel et al. (1985). For the southern part of the valley, no such trend was recorded (Büsselberg 1985; Salzwedel et al. 1985).

The three associations (station groups) of the Pleistocene Elbe valley are distinguished by their characterizing and discriminating species. The method of calculating discriminators has a major disadvantage, as presence within a station group is not considered sufficiently. Also in our case, fidelities of presence of the discriminating species of station groups Northwest and Centre are low. Therefore, only characterizing species were taken into consideration for the description of the association of station group Northwest. Station group Centre lacks both characterizing species and discriminators with high fidelity of presence, since the elements of its fauna are represented too strongly within both the other associations. The only species that was found exclusively in this association was the polychaete Podarkeopsis helgolandica, of which only two specimens were found. Therefore, this association is regarded as a transitional one, situated around a depth of $40 \mathrm{~m}$, connecting the north-western and the southeastern associations. The $40 \mathrm{~m}$ depth line was also described as a border between the two fine sediment communities of the inner and the outer Exclusive Economical Zone of Germany (Rachor and Nehmer 2003). In the report of the Study Group on the North Sea Benthos Project (ICES SGNSBP Report 2006), the boundary of the two muddy communities of the southern North Sea is $35 \mathrm{~m}$. The transitional association is marked by a low number of species compared to the other associations, which is probably only due to the much lower number of grab samples taken in this association. For the description of station group Southeast, the seven characterizing species were reduced by selecting those species, which are both characterizing and discriminating. Only the two species $A$. brachiata and Tellimya-ferruginosa meet both criteria.

Consequently, two main associations along the Pleistocene Elbe valley were found. The Amphiurabrachiata-Tellimya-ferruginosa-association is located in the south eastern part of the submersed valley, whereas the Amphiura-filiformis-Galathowenia-oculata-Nuculoma-tenuis-association is located in the north western valley. In between, there is a transitional association with elements of the faunas of both other associations.

When the structure of the macrozoobenthic community described above is viewed in the context of the entire study conducted by Rachor and Nehmer (2003), there is no evidence for additional associations within the Pleistocene Elbe valley. Thus, the associations found in this study have to be considered small-scale structures within the Nucula-nitidosa-community and 
the Amphiura-filiformis-community (see Rachor and Nehmer 2003). In the ICES SGNSBP Report (2006), two communities are described for muddy sediments of the Exclusive Economical Zone of Germany as well, but the intermediate part of the Pleistocene Elbe valley is inhabited by both communities, which might reflect the transition recorded in the present study.

Nevertheless, in the years 1983-1988, three associations within the submersed Pleistocene Elbe valley were found by Künitzer (1990), which correspond very closely with the associations of the present study. The characterizing species of the Amphiura-filiformisGalathowenia-oculata-Nuculoma-tenuis-association appeared with constant dominance in the northern association during these years. The polychaete Spiophanes bombyx was the only dominant species of the intermediate part of the valley, which occurred in both studies. Dominant species of the southern part of the Pleistocene Elbe valley which were found by Künitzer (1990) as well were Phoronis spp., Nucula nitidosa, Scalibregma inflatum, Nephtys hombergii, and Mysella bidentata. As stated by Künitzer, the most dominant species was Ophiura albida, which was not among the dominant species in the Amphiura-brachiata-Tellimyaferruginosa-association of the present examination.

In the study of the southern Pleistocene Elbe valley of Büsselberg (1985), the benthic community was even more different from the present study. The Amphiurafiliformis-association with species of the Nucula-nitidosa-association found in 1984 comprised an area, which contained the stations $471 / \mathrm{UT} 13$ and 472 of the present study. Chaetopterus variopedatus, Gattyana cirrosa, Ampharete sp., Lagis (Pectinaria) koreni, and S. inflatum were characteristic representatives of this association. During our study, Ch. variopedatus was limited to the northern-most part of the Pleistocene Elbe valley, G. cirrosa occurred in the central and northern part, Lagis koreni was found in almost all samples with a maximum in the northern part of the area, and $S$. inflatum was recorded in the entire southern part of the valley. Characteristic species found during our study were A. filiformis and Magelona filiformis.

The Amphiura-filiformis/Tellina-fabula-association mentioned by Büsselberg (1985) is situated in the area of stations 563, 564, and 565 during 2000. Typical species of the association were A. filiformis, Magelona johnstoni, Magelona minuta, Fabulina (Tellina) fabula, and Perioculodes longimanus. In 2000/2001, A. filiformis was only recorded at station 563 , which was the southern border of its distribution. M. johnstoni occurred only at station 471 and M. minuta was only found at station 562. F. fabula was recorded from stations 564, 563, and the southernmost area of the Pleis- tocene Elbe valley. P. longimanus, however, occurred in the entire area and north of it.

The northern-most and most specious association of the year 1984 was the Amphiura-filliformis-association, which corresponded with our stations 554 and 562 . Most important faunistic elements of this association were Eulima alba, Pectinaria (Amphictene) auricoma, $H$. antennaria, and Diastylis rathkei. The only one species recorded again in the years 2000 and 2001 was H. antennaria. A auricoma was found northward only.

The present study shows that serious changes in the community of the Pleistocene Elbe valley have taken place over the past two decades. Of the characteristic species of 1984, M. johnstoni and M. minuta were only found with a few specimens in 2000; others such as the polychaetes Amphictene auricoma, G. cirrosa, and C. variopedatus drew back into deeper areas of the Pleistocene Elbe valley. Chamelea gallina occurred along the entire southern Pleistocene Elbe valley in 1984, while in 2000 it was found only at one station. The most important change we recorded was the substitution of the characterizing species Amphiura filliformis, which was formerly an important element along the total Pleistocene Elbe valley. During the present study, the southern association was characterized by $A$. brachiata instead of A. filiformis.

Both are important species of the community of muddy sediments of the Bay Biscay. A. brachiata and Clymene oerstedi are characteristic in the "Infralittoral Étage"; the "Étage du large" is characterized by A. filiformis and Tellina serrata (Glémarec 1973). Both ophiurids are most important characterizing species of the associations of the submersed Pleistocene Elbe valley, too. Obviously, there was some kind of shift of the community of the Pleisocene Elbe valley towards a community comparable to that of the Bay of Biscay. After Kröncke et al. (2001), a shift of the macrozoobenthic community off Norderney since 1988 is connected to the increase of the North Atlantic Oscillation Index (NAOI). A positive value of the NAOI indicates a warm and moist winter. Since 1971, no period with negative values in at least three consecutive years was recorded (Hurrell 1995, also compare http://www.jisao. washington.edu/data_sets/nao/).

A consequence of this seemingly recent warming could be a shift of the southern North Sea towards conditions of Atlantic waters. In this case, the Helgoland Deep Trench could prove to be a refuge for formerly common boreal species. Here, stratification of the water column is possible due to a comparatively high depth (up to $60 \mathrm{~m}$ ) and the special current of the trench. Thus, independent of season cold high-saline bottom water can persist in the trench (Caspers 1939). 
Acknowledgements We would like to thank the crews of RVs "Heincke" and "Uthörn" for their help and assistance at sea. Also, thanks to Elke Barwich and Dr. Sergej Gagaev for their support in determining polychaetes.

\section{References}

Becker GA (1990) Die Nordsee als physikalisches System. In: Lozán JL, Lenz W, Rachor E, Watermann B, Westernhagen $\mathrm{H}$ (eds) Warnsignale aus der Nordsee. Parey, Berlin Hamburg, pp 11-27

Berberich D (1989) Vergleichende Untersuchungen zur Artenzusammensetzung, Abundanz und Biomasse des Makrozoobenthos der Helgoländer Tiefen Rinne von 1936/37 und 1988/89. Diploma thesis, Technische Hochschule Darmstadt, Germany

Bray JR, Curtis JT (1957) An ordination of the upland forest of southern Wisconsin. Ecol Monogr 27:225-349

Brey T (2001) Population dynamics in benthic invertebrates. A virtual handbook. http://www.awi-bremerhaven.de/Benthic/ Ecosystem/FoodWeb/Handbook/main.html

Büsselberg D (1985) Kartierung des Makrozoobenthos im ElbeUrstromtal der Deutschen Bucht. Diploma thesis, Universität Hohenheim, Germany

Caspers H (1939) Die Bodenfauna der Helgoländer Tiefen Rinne. Helgol Wiss Meeresunters 2:1-112

Clarke KR, Warwick RM (1994) Change in marine communities: an approach to statistical analysis and interpretation. Natural Environment Research Council, Plymouth, UK

Duineveld GCA, Künitzer A, Niermann U, De Wilde PAWJ, Gray JS (1991) The macrozoobenthos of the North Sea. Neth J Sea Res 28:53-65

Figge K (1980) Das Elbe-Urstromtal im Bereich der Deutschen Bucht (Nordsee). Eiszeitalter und Gegenwart 30:203-211

Glémarec M (1973) The benthic communities of the European North Atlantic shelf. Oceanogr Mar Biol Ann Rev 11:263-289

Hagmeier A (1925) Vorläufiger Bericht über die vorbereitenden Untersuchungen der Bodenfauna der Deutschen Bucht mit dem Petersen-Bodengreifer. Ber Dt Wiss Komm Meeresforsch N F 1:247-272

Heip C, Basford D, Craeymeersch JA, Dewarumez J-M, Dörjes J, De Wilde P, Duineveld G, Eleftheriou A, Herman PMJ, Niermann U, Kingston P, Künitzer A, Rachor E, Rumohr H, Soetaert K, Soltwedel T (1992) Trends in biomass, density and diversity of the North Sea macrofauna. ICES J Mar Sci 49:13-22

Hurrell WH (1995) Decadal trends in the North Atlantic oscillation: regional temperatures and precipitation. Science 269:676-678

ICES (2006) Report of the study group on the North Sea Benthos Project 2000 (SGNSBP) 10-13 April 2006 Nioz, Texel, The Netherlands. ICES CM 2006/MHC 06

Kröncke I, Rachor E (1992) Macrofauna investigations along a transect from the inner German bight towards the Dogger bank. Mar Ecol Prog Ser 91:269-276
Kröncke I, Zeiss B, Rensing C (2001) Long-term variability in macrofauna species composition off the island of Norderney (East Frisia, Germany) in relation to changes in climatic and environmental conditions. Senckenb Marit 31:65-82

Künitzer A (1990) Zur Verbreitung und Populationsdynamik der Bodenfauna der zentralen Nordsee. Dissertation, Universität Bremen, Germany

Künitzer A, Basford D, Craeymeersch JA, Dewarumez JM, Dörjes J, Duineveld GCA, Eleftheriou A, Heip C, Herman P, Kingston P, Niermann U, Rachor E, Rumohr H, de Wilde PAJ (1992) The benthic fauna of the North Sea: species distribution and assemblages. ICES J Mar Sci 49:127-143

Petersen CGJ (1914) Valuation of the sea II. The animal communities of the sea-bottom and their importance for marine zoogeography. Rep Dan Biol Stn 21:1-44

Pielou EC (1966) The measurement of diversity in different types of biological collections. J Theor Biol 13:131-144

Rachor E (1982) Biomass distribution and production estimates of macro-endofauna in the North Sea. ICES CM 1982/L 2

Rachor E (1990) Changes in sublittoral zoobenthos in the German Bight with regard to eutrophication. Neth J Sea Res 25:209-227

Rachor E (2006) Search for particular valuable benthic areas in the German North Sea EEZ. In: von Nordheim H, Boedecker D, Krause JC (eds) Progress in marine conservation in Europe: NATURA 2000 sites in German offshore waters. Springer, Berlin, pp 127-140

Rachor E, Albrecht H (1983) Sauerstoff-Mangel im Bodenwasser der Deutschen Bucht. Veröff Inst Meeresforsch Bremerh 19:209-227

Rachor E, Nehmer P (2003) Erfassung und Bewertung ökologisch wertvoller Lebensräume in der Nordsee. AWI Bremerhaven (on behalf of the Federal Agency of Nature Conservation of Germany/BfN):1-177, published at: http:// www.bfn.de/marinehabitate/de/downloads/berichte/Benthos_oekolog_Untersuchungen_Nordsee_2004.pdf

Radach G (1998) Quantification of long-term changes in the German Bight using an ecological development index. ICES J Mar Sci 55:587-599

Rehm P (2002) Das Makrozoobenthos im Elbe-Urstromtal. Diploma thesis, Universität Marburg, Germany

Salzwedel HL, Rachor E, Gerdes D (1985) Benthic macrofauna communities in the German Bight. Veröff Inst Meeresforsch Bremerh 20:199-267

Schröder A (2003) Community dynamics and development of soft bottom macrozoobenthos in the German Bight (North Sea) 1969-2000. Dissertation, Universität Bremen, Germany

Shannon CE, Weaver W (1949) The mathematical theory of communication. University of Illinois Press, Urbana

Stripp K (1969) Die Assoziationen des Benthos in der Helgoländer Bucht. Veröff Inst Meeresforsch Bremerh 12:95-142

Thatje S, Gerdes D (1997) The macrofauna of the inner German Bight: present and past. Arch Fish Mar Res 45:93-112 